\title{
Coinfecção com vírus rábico e Clostridium chauvoei em um bezerro
}

Giulia Ferreira Souza Ricaldi", Roberio Gomes Olinda, Lisanka Ângelo Maia, David Driemeier, Tatiane Rodrigues da Silva, Glauco José Nogueira de Galiza,Antônio Flávio Medeiros Dantas

Universidade Federal de Campina Grande (UFCG), Campina Grande, PB, Brasil

*Autor correspondente

e-mail: giuliaricaldiaju@hotmail.com

\section{Resumo}

A raiva é uma doença que acomete animais domésticos, silvestres e humanos. É transmitida principalmente pela mordedura de morcegos hematófagos, causando uma encefalite ou mielite não supurativa. Esta enfermidade é uma importante causa de morte em bovinos na região Nordeste. 0 carbúnculo sintomático é uma enfermidade causada pela infecção por Clostridium chauvoei, que resulta em necrose e hemorragia de músculos estriados. Infecções mistas do vírus da raiva não são comuns, embora existam relatos da associação com o herpesvírus bovino tipo 5 e na intoxicação natural por Sida carpinifolia. Este trabalho tem como objetivo descrever as alterações clínico-patológicas de um caso de raiva associado a carbúnculo sintomático em um bezerro. Um bovino, da raça Nelore, macho, com um ano de idade, apresentava paresia dos membros pélvicos, ataxia, nistagmo, tremores de cabeça e decúbito esternal há três dias. 0 animal não era vacinado para raiva e nem para clostridioses. Na necropsia, ao realizar a palpação do membro pélvico direito evidenciou-se que os músculos estavam aumentados de volume e creptantes. Nos músculos esqueléticos observavam-se áreas multifocais vermelho-enegrecidas, secas, friáveis, porosas e enfisematosas, distendidas por exsudato serohemorrágico. Microscopicamente, nos músculos esqueléticos observavam-se áreas extensas de necrose das miofobras associadas à hemorragia, edema, fibrina e neutrófilos degenerados entre as miofibras e fascículos musculares. Observavam-se também áreas multifocais de degeneração das fibras musculares associadas a espaços circunscritos e bem delimitados (enfisema). Numerosos bacilos gram positivos com esporos subterminais foram visualizados no interior da lesão. No encéfalo foi observado infiltrado inflamatório mononuclear nos espaços perivascular, além de marcada gliose multifocal e meningite não supurativa. No gânglio de Gasser havia moderado infiltrado inflamatório mononuclear, necrose neuronal e neuroniofagia. Inclusões intracitoplasmáticas eosinofílicas (corpúsculo de Negri) em neurônios foram 
observadas no encéfalo e no gânglio de Gasser. Na imuno-histoquímica houve forte imunomarcação do antígeno rábico no citoplasma das células de Purkinje, em seus prolongamentos e na camada granular do cerebelo. A identificação de coinfecção do vírus da raiva com outras enfermidades em bovinos é de extrema importância para a adoção de medidas de controle e prevenção. Além disso, uma análise detalhada de todos os órgãos é imprescindível para o diagnóstico preciso. 